\title{
Political displacements between the periphery and the center through territories and bodies
}

\author{
Rachel Barros \\ Juliana Farias
}

CIDADES - Urban Research Nucleus, Programa de Pós-Graduação em Ciências Sociais - PPCIS, Universidade do Estado do Rio de Janeiro - UERJ, Rio de Janeiro/RJ, Brasil

\begin{abstract}
How does the actualization of government technologies in territories considered to be on the margin of the State work? Which theoretical and methodological clues can we follow from the marks left by State agents on the bodies of those regarded as peripheral? What are the political connections between territorial boundaries and the delimitations of the physical bodies that inhabit them? These questions inform the present article in which we analyze three homicides by pursuing two complementary lines of investigation: one guided by the reflection on the territorialization of certain State actions, in the sense proposed by Barros (2016); the other anchored in the discussion on the mechanisms central to the governmental management of the deaths of favela residents, as outlined by Farias (2014).
\end{abstract}

Keywords: state violence; favelas; government technologies; summary execution; bodies. 


\section{Deslocamentos políticos entre periferia e centro através de territórios e corpos}

\section{Resumo}

Como se dão as atualizações das tecnologias governamentais em territórios considerados à margem do Estado? Quais pistas teórico-metodológicas podemos perseguir a partir das marcas deixadas por agentes de estado em corpos considerados periféricos? Quais são as conexões políticas entre as fronteiras territoriais e as delimitações do corpo físico que as habita? Tais perguntas alimentam a elaboração deste artigo, no qual analisamos três casos de homicídio a partir de duas linhas investigativas complementares: uma pautada pela reflexão sobre a territorialização de determinadas ações de Estado, no sentido proposto por Barros (2016), e outra ancorada na discussão sobre a engrenagem que compõe a gestão governamental das mortes de moradores de favelas, nos termos trabalhados por Farias (2014).

Palavras-chave: Violência de Estado; favelas; tecnologias de governo; execução sumária; corpos. 


\title{
Political displacements between the periphery and the center through territories and bodies
}

\author{
Rachel Barros \\ Juliana Farias
}

\section{Introduction'}

How does the actualization ${ }^{2}$ of government technologies in territories considered to be on the margin of the State work? Which theoretical and methodological clues can we follow from the marks left by State agents on the bodies of those regarded as peripheral? What are the political connections between territorial boundaries and the delimitations of the physical bodies that inhabit them? These questions inform the present article in which we analyze three homicides by pursuing two complementary lines of investigation: one guided by the reflection on the territorialization of certain State actions, in the sense proposed by Barros (2016); the other anchored in the discussion on the mechanisms central to the governmental management of the deaths of favela residents, as outlined by Farias (2014). ${ }^{3}$

This text is built, therefore, on two distinct ethnographies, whose points of political-theoreticalmethodological intersection reflect our commitment to the Manguinhos Social Forum and the Network of Communities and Movements against Violence - social movements through which the two research agendas concerned were undertaken. In the present joint text, we turn our attention to the first three deaths to result from police intervention after the implementation of the Pacifying Police Unit (UPP) in Manguinhos, in the North Zone of the city of Rio de Janeiro. ${ }^{4}$

Based on these three cases, ${ }^{5}$ we shall examine various political displacements related to the interweaving of center and periphery, engaging with two of the definitions formulated by Veena Das and Deborah Poole in their analysis of anthropology as practiced on the "margins of the State": one is the notion of margins as places where rights can be violated through different dynamics of interaction between people and the documents, practices and words of the State (Das \& Poole, 2004:9); the other approaches the margin as "a space between bodies, laws, and discipline" (Das \& Poole, 2004:10).

\footnotetext{
1 We are very grateful to Ana Luiza Lopes and Rodrigo Calvet for their careful translation of our article.

2 At this point, we wish to emphasize the meaning we hope to convey by the terms actualization and actualize, which translate the Portuguese words atualização and atualizar, meaning both 'make actual/real' as well as 'renew, update.' This choice reflects our understanding of given State practices as the accumulation of experiences that are also being continually reinvented. That is to say, they hinge on violation techniques from the past while they simultaneously update - or actualize - themselves with whatever resources they need in order to control bodies and territories in the present.

3 We wish to thank the mothers and relatives of victims of state violence who work in Rio de Janeiro, especially Ana Paula Oliveira and Fátima Pinho, for providing the documentation analyzed in the present article, as well as the trust of politically engaged groups with whom we conduct(ed) our research: in Rachel Barros's case the Manguinhos Social Forum, and in Juliana Farias's, the Network of Communities and Movements against Violence.
}

4 According to Barros (2016), the neighborhood of Manguinhos encompasses twelve favelas, while the so-called Manguinhos Complex as a whole is composed of sixteen favelas. For more information, see Projeto Território em Transe (http://www.territorioemtranse.com.br), the web portal of the Laboratório Territorial de Manguinhos - LTM/Fiocruz (www.conhecendomanguinhos.fiocruz.br), as well as História de pessoas elugares (LTM/Fiocruz, 2009) and Diagnóstico sócio comunitário de Manguinhos (Laboratório de Direitos Humanos de Manguinhos, 2011).

5 In our analysis we have adopted the term 'case' as an emic category, which within this ethnographic context, corresponds to an emblematic instance of summary execution. However, we also value the political perspective that the idea of 'case' provides, as expressed in the works of Freire (2005, 2007, 2008, 2010), who, inspired by the analyses of Boltanski (1990) and Claverie (1998), reads the 'form-case' as a resource available for use within the political framework. 
Lastly, it is important to point out that we appreciate the idea that the delimitation of such "margins of the State" is not solely based on geographical aspects: the shift from a spatial model of center and periphery relates to the understanding that various notions of 'margins,' as they were explored in the seminar that gave rise to Anthropology in the Margins of the State, were based on relations between sovereignty and forms of disciplinary power, as well as on specific genealogies of political and economic subjects (Das \& Poole, 2004) ${ }^{6}$

\section{March 17, 2013: the Case of Mateus Oliveira Casé}

Sixteen year-old Mateus Oliveira Casé died during a police search in the Américo Junior Square, in Vila Turismo.7 According to a document sent to the UN Rapporteur of the United Nations for Summary, Arbitrary and Extrajudicial Executions, " "Mateus was with a group of friends when a police car used by the local UPP stopped near them. One of the police officers said, "look who fell into my hands." The same document states that this officer had a 'disagreement' with Mateus only days before the approach that led to the Taser weapon being fired. When Mateus was hit, he was electrocuted, fell and banged his head on the ground. One of the witnesses declared that the police officers said Mateus would wake up in two hours. They left without assisting the victim. Local residents then decided to take the young man themselves to the Emergence Care Unit, where he was pronounced dead on arrival. ${ }^{9}$

The Pacifying Police Unit had been implemented on January $16^{\text {th }} 2013$, just two months prior to Mateus's death. The proximity of these dates is an important element in the present analysis, as will become clear in the following sequence of statements, beginning with an excerpt from a speech by Captain Martins, in charge of the Manguinhos UPP at the time. During a community meeting to discuss the case of Mateus's death, Captain Martins presented several arguments delegitimizing the claims of local residents concerning the facts - arguments that comprise at least two versions, both based on legal procedures that granted veracity to the officer's allegations.

In his first version of the events, the captain stated that the UPP officers did not use the Taser gun, claiming such a weapon would be unlikely to have caused the young man's death. Captain Martins explores the alleged contradictory testimonies from the people who were with Mateus in order to legitimize this version of the facts, which points to the young man banging his head as the cause of death:

These same people said they tried to wake the boy up with alcohol [...] and he did not respond, then they tried to give him a glass of milk, and he was still unconscious. Well, I don't know why they thought that a glass of milk would wake him up, but that was the procedure they adopted. They saw it didn't work. That was when somebody decided to take him to the UPA [Emergency Care Unit], and we already know the outcome. Anyway, they were only unanimous in the end when they said the boy had hit his head. Because they were informed that the shock would be unlikely to lead to someone's death, they said the boy had hit his head, and that this blow to the head was what probably caused him to die. ${ }^{10}$

6 We point out that despite expressing the influence of Veena Das and Deborah Pool's thinking on "margins of the State," our analysis also stems from our reading of Foucault's notion of 'governmentality.' We therefore intend 'margins of the State,' 'governmentality' and 'governmental management of bodies and territories' to be explored here through an ethnographically productive conceptual tension.

7 Vila Turismo, whose emergence dates back to 1951, is one of the favelas in Manguinhos.

8 In this document, the report on Mateus's case was submitted by the team from the Institutional Violence and Public Safety program of the NGO Justiça Global, in close dialogue with members of the Manguinhos Social Forum, as well as members of the Human Rights and Citizenship Defense Committee of the State Assembly of Rio de Janeiro. To access the whole document, see "Information regarding human rights violations in Rio de Janeiro occupied 'favelas' - the case of the 'Unidades de Polícia Pacificadora' (Police Pacifying Unit) and recent killing during the protest season in Brazil," source <http://www.global.org.br/ wp-content/uploads/2016/03/Global-Justice-Information-regarding-human-rights-violations-in-Rio-de-Janeiro-occupied----favelas---.pdf>.

9 According to information provided by TV Record, the Health Office responsible for the Manguinhos Emergency Care Unit had released a statement informing that Mateus was dead on arrival. See <http://tv.r7.com/record-play/rio-de-janeiro/balanco-geral-rj/videos/policiais-e-moradores-entram-emconfronto-apos-morte-de-jovem-em-manguinhos-rj-18102015>.

10 Excerpt from an audiovisual recording of the $2^{\text {nd }}$ community meeting of the local UPP, held in June 2013. 
Captain Martins's subsequent arguments added elements to the narrative drawn from the world of forensic medicine, creating a mosaic of technical information whose purpose was to invalidate the claims of the residents who held the police responsible for Mateus's death.

But when this information came to me, I already knew the boy had no marks, any mark, no lesion on the body, including from the Taser equipment... That equipment leaves a mark. If someone has never seen it in use, it leaves a mark, it leaves a small lesion, it is not big, but nevertheless it leaves a lesion when directly applied to the body; when used with a dart, it perforates. Only a doctor can remove it, only a medical team can remove the dart, because it really penetrates the skin, there is no way the person can take it off. If the person tries to take it off, it will get even worse. So every time it is used, it is recommended... it is recommended, the protocol is that the police squad will help the person who was...uhhh... on whom the equipment was used, they help the person and take him to the medical team so they can remove that dart. In other words, the dart was not used, nor was the equipment directly. There was no mark. There was also no mark on the head. There was no mark on the body. So, the version of the fall, of the beating, of anything, it all fell apart. Well, I am not going into the merits, well, of why they claimed that, I will not judge... they were friends, family, anyway, they associated it with the police check and accused the officers of the fact."

Reinforcing the version that there was no mark on the victim's body connecting the crime to the officers, Captain Martins attempts to bolster his narrative by describing the physical transformations caused by the shot of a Taser weapon with a dart - the lesion it leaves when directly applied to the body, the perforation of an object that "really penetrates the skin." He then contrasts these effects with the supposed standard action of the police, who must follow regulations (a determinação or protocol as he calls it) when choosing to employ such equipment, namely, to provide aid to the victim. However, this very narrative highlights the differences between the care taken with the body of a resident and the care taken with the corporation's apparatuses. After all, the control technologies employed by the police include not only equipment and weaponry, but also the official state narrative, duly utilized and edited to justify successes and mistakes.

Well, this resulted in a series of disturbances, they attacked the police car, they tried to attack buses, the community was in terrible chaos. And, naturally, stun grenades had to be used... [a resident then adds, "guns too, right captain, guns too." And he replies:] they ended up being wrongfully used, both officers are being questioned about that.

Resident: And how is the death inquest going?

Captain: Death inquest?

Resident: Is there no inquest?

Captain: Look...

Resident: If there is a complaint from the residents, isn't there an inquest?

Captain: Let me finish, I will get there. Anyway... There were a series of disturbances, creating a terrible, terrible atmosphere in the community, and this information that the boy had been killed by the UPP was first broadcasted by the R7 website, then by the TV channel Record, and finally by the residents themselves who, hearing this story, naturally reproduced it, okay, then, naturally, there is no way to blame anyone for anything, this is actually why I am here right now clarifying this. ${ }^{12}$

\section{Ibid.}

12 Ibid. 
The official statement above was made during an open meeting with residents. This places us in a privileged position to observe how the process of actualizing governmental control techniques feeds on the practice Foucault (1988) called "discursive orthopedics," since the police officer selects which information to disclose and which to withhold. Moreover, there is a specific format for revealing the information to be disclosed, just as Foucault (1988) discusses through the notions of policing of statements and control over enunciations.

This is not about the production of State control over what is said or not said concerning the deaths resulting from police intervention. What is actually at stake is the production of determinations on different ways of not saying things: how those who can and cannot speak are distributed, what type of discourse is allowed, or what kind of description is demanded from whom (Foucault 1988:34). It is no coincidence that the captain uses the term 'clarification' here. It is precisely by pursuing a 'clarification of facts' narrative that the State agent continues to ratify his version of Mateus's death.

Beginning to answer our friend here [he points at the resident who has asked about the inquest], regarding the investigation: first, the preliminary report from the Civil Police, from the Medical-Legal Institute, the cause of death, uhhh...[was] cardiorespiratory arrest, and the body presented a mild... I can't remember the technical term right now, but anyway... the lung was slightly swollen and there was liquid, liquid residue in the lung, anyway... it was confirmed once again: there was no sign of violence on the boy's body. There was none, okay? And this isn't the final report. We are still waiting for the final one. Now, the first piece of information we received from the Medical-Legal Institute team that examined the boy was that he probably suffocated from some liquid. And then the version I was told was that... was that someone gave a glass of milk to the boy while he was unconscious. I am not an expert, I am waiting, but everything suggests... everything suggests that the boy ended up suffocating because someone gave him a glass of milk while he was unconscious. Okay? There is, uhhh... an investigation being conducted within the Military Police... The Civil Police, uhhh... if I'm not mistaken, they are also investigating the... the boy's death, now, uhhh... the evidence, the evidence so far, let me say this again, is that there was no fact of violence regarding the police action. ${ }^{13}$

Forgetting the technical term, saying he had no access to the final report, and stating Mateus "probably suffocated with some liquid" constitute discursive strategies, which are also 'ways of not saying,' yet saying. The captain thus fits the pieces of the narrative inherent to the actualization of the State's 'fiction of power,' as outlined by Mombaça (2016). According to the latter, the "monopoly of violence is a fiction of power based on the promise that it would be possible to forge a neutral position from which to mediate conflicts" (Mombaça 2016: 14). This 'fiction of power' thus entitles the captain to declare that, 'naturally,' police officers used stun grenades when they identified 'disturbances' and 'terrible chaos' within the community. Built on the elasticity inherent to the process through which such fictions are constructed, the captain presents a second version of Mateus's death, which complements the first one, bringing a moral judgement with it. He invokes "the evidence" to claim that the young man died of an overdose, not to mention that the residents are directly blamed for his death, since according to the captain's version, they prevented the police from providing assistance:

Well, shortly afterwards, I did check whether there had been at least one approach by the officers. I found out there was indeed one approach. What happened? As the officers reported, they saw a group of young men and approached them, they were met with resistance on this first approach, and one of those boys who had not yet been approached, had not yet been searched, uttered some words, uhhh... he cursed the officers, cursed the squad, and ran off. At that moment, the squad left the group that was being approached and ran after the boy. 
And if he fled, he must have had a reason to flee. They ran after him but couldn't catch him. Anyone who knows Vila Turismo, that part over there, those little alleys over there, knows that, man, losing someone is the easiest thing to do when entering that area, because they are not... they are not Cartesian [in a geometrically ordered grid], anyway, and an alley divides into 2, 3, it is very easy for you to lose sight. Anyway, they lost sight of the boy, they didn't see where he went. They went back to the spot where they had first approached the group. When they returned, the boy who would pass away was already down, and they questioned the girl who later came to me and spoke about the whole incident. They asked the girl what happened, and she said that there was no problem, that he was sick because - these were the words reported to me - because he was high. Information I had received from that first resident at the beginning of the story, who reported those facts to me. He said the boy had been using drugs since the night before. He spent the night using drugs. Well, the fact is they asked what was going on, the girl [said]: "no, he is sick because he is high." "Okay, let's take him to the UPA then" [officer's words] - "no, you're not going to lay a hand on him, you won't take him anywhere" [the girl's words]. So what did the officer do? He left the scene, proceeded with his normal duties after being misled into thinking there was nothing more serious. For those who are in contact with drug users, they know that it's not unusual for a drug user to feel sick, faint, anyway, when using continuously. So, anyway, the fact that the boy was down for no apparent reason was not strange enough for the officer to help the boy against their [the local residents'] will. Because his friends didn't want to let them assist him. So the officer proceeded with his normal duties, and the rest of the story you already know. [...] As I said, the fact is being checked, we opened an inquest, the Military Police opened an inquest because there was a complaint by the residents, a complaint that was reported by the media. Now, in the preliminary inquest, there was no evidence, I repeat, there was no evidence of irregular conduct by the officers, okay? And I say this with complete peace of mind, because you may think 'But the captain is defending his officer.' Of course not. And then I go back to the point mentioned by our friend over there, the two officers who shot into the air to contain a disturbance... [residents interrupt and say the shots were not fired into the air, but towards the people, and add 'it's on film, captain.' And the captain asks:] Towards the people?

Residents: It's on film.

Captain: Look, do you understand anything about shooting, about weapons?

Resident: And do you understand anything about social policies?

Captain: You are completely wrong, completely wrong, let's do this, let me conclude and then you speak, I can see you are here just to question. Without any grounds.

Residents: This is our role.

Captain: So I'll respect your role. Just to conclude then, and open the agenda, I felt compelled to provide a clarification, to present another version to the residents, because it's too easy, the press throws the information into the media without any basis [in fact], the R7 website reported the boy had been killed by [electric] shock, and there was no reporter from Record here at the moment. [...] The irresponsibility, the recklessness of a mass information agency that dumps the information without checking it, without verifying it, and manipulates it, on purpose or not, I don't know to what end, it manipulates all the information, and then you discover that the story wasn't quite like this. ${ }^{14}$ 
In this latter - and longer - excerpt from the recording of the meeting, it becomes even clearer that the historically constructed confrontation represented by the State-favela relationship ${ }^{15}$ is actualized in the meeting itself. This is apparent, for example, when the captain monopolizes the meeting and does not know how to handle the interruptions from the residents, when he announces that he went on to check whether or not there had been an approach (information which, by that point, had been confirmed by different witnesses - albeit witnesses whose words apparently mattered less than the words of 'his officer,' in this case, the officer who answered to the local UPP command). This confrontation also becomes clear when he invokes the specificities of a field of knowledge in order to challenge information provided by the residents (“Look, do you understand anything about shooting, about weapons?").

Not even when confronted with the video record ${ }^{16}$ - which proves visual proof of the fact that at least two UPP agents had shot towards residents occupying a public space and expressing their outrage at Mateus's death - did the captain allow the 'community meeting' (according to his own terms) to resemble a space of 'discussion' with an 'open agenda,' as he had announced when beginning his talk that day. The intrinsic asymmetry of the meeting only seems to increase as his narrative develops. This is not just due to the fact that the captain's body was wrapped in a Military Police uniform, with decorations displayed on his shoulders and the flag of the state of Rio de Janeiro emblazoned on his right sleeve, but also because his body condensed the image of a State that sees itself as sovereign and the sole bearer of the right to use force. Not to mention that the sound of the words, which articulate the arguments necessary to the construction process of the "fiction of power," are uttered through this same body (Mombaça 2016).17

Such fiction is an essential element in the actualization of governmental control technologies, since the State must continuously re-create boundaries to become sovereign vis-à-vis certain populations and in certain territories: imagining the figure of the law depends on creating boundaries between practices and spaces included as part of the State and those excluded from it (Das \& Poole 2004). The captain has to say that the residents were there "just to question," "without any grounds," while he positions himself as the expert, a master of investigative techniques, a specialist in handling firearms, and an authority on the law who "felt compelled to provide a clarification, to present another version to the residents."

In the situation under question, the boundaries of the Manguinhos territory were re-created through the action of the officers of the newly-implemented Pacifying Police Unit (UPP) - whether those performing patrols on foot or in police vehicles, approaching residents aggressively, or those who control the information during a meeting like the one cited to the point of denying facts that were recorded on video and broadcast on open TV and the internet. This is the sort of boundary demarcation that validates improbable facts, deletes the action of key actors (like the officers who shot towards the residents rather than in the air) from the scene, pushes central issues to the margins of the meeting agenda (the residents asked about the inquest, but based on a preliminary inquiry and on the forgotten technical term, the captain asserted that "there was no evidence of irregular conduct by the officers").

\footnotetext{
15 We turn our attention to the management of the population living in the favelas, considering the connection existing between the current public safety policies and the policies aimed at these people and territories due to their identification (specially by the public power) as an aesthetic blemish or a threat to the city's health, as Valladares's analyses show $(2000,2005)$. We argue that this connection between current public safety policies aimed at the favela territories and peripheries and the public policies for social assistance, health and housing is necessarily traversed by dynamics of violence, analyzed in different studies on segregation, conflict, circulation and political disputes from research lines that share reflections on the relationship between the State and its 'margins,' such as Machado da Silva (2008, 2016), Birman (2008), Magalhães (2008, 2013), Guariento (2009), Landim \& Guariento (2010), Telles (2010), Feltran (2011), Leite (2012), Mattos (2013), Rodrigues et al. (2012), Trindade (2012), Cunha and Feltran (2013), Vianna (2014), Fernandes (2013), Landim (2013), Landim \& Siqueira (2013), Rocha (2013), Menezes (2015), Birman, Leite, Machado \& Carneiro (2015), Guterres (2016).

16 The record is available at $\langle\mathrm{http}: / / \mathrm{r} 7 . \mathrm{com} / \mathrm{Fg} 6 \mathrm{l}\rangle$.

17 We call attention to the fact that the 'fiction of power' notion, as formulated by Mombaça (2016), is articulated, therefore, with the performative dimension that produces/becomes the State and margins.
} 
The displacement of territorial boundaries is necessarily articulated with the displacement of the political and moral boundaries of the residents, and the "fiction of power" produces fatal victims, like Mateus. The narrative that serves the fiction of power even modifies the physical body of the victim, whose death is sometimes attributed to the blow on the head when falling and sometimes to choking with liquid. Thus the cause of death remains invisible, just like the injuries that were never found on the body - after all the Taser gun was not even used, indeed the weapon is not even on the list of equipment used by agents of the UPP implemented in Manguinhos. ${ }^{18}$ But when it comes to the death of peripheral bodies, military authorities do not have to be 'Cartesian' in their explanations, which can be like the 'little alleys' in Vila Turismo, where an "alley divides into 2, 3 " and "it is very easy for you to lose sight."

In this process of continual boundary redefinition, even an electric shock denied by the official discourse is capable of determining what is marginal and what is central, reminding us of the relevance of understanding margins as "a localized space among bodies, laws, and discipline." The distance between a Taser weapon that does not exist at the Manguinhos UPP and Mateus's body redefined a new margin, where the question of the origin of the law emerges not as the myth of the State but, following the formulations of Das and Poole (2004), actualized by men whose abilities to represent the State or to enforce its laws are localized in a disposition to move with impunity between what appears permissible under the law and the extrajudicial.

\section{October 17, 2013: the Case of Paulo Roberto Pinho de Menezes}

In the early hours of October 17, 2013, Paulo Roberto Pinho de Menezes, 18 years old, was in the area known as Coréia with a group of friends. According to people who witnessed the event, UPP officers cornered the young man in an alley and beat him to death. In the afternoon, the mood at the scene was very tense, and the younger residents seemed to be the most outraged with the young man's death. They threw rocks at the UPP base near the alley where Paulo Roberto was murdered, and a young woman who witnessed his death was shot in the leg, which provided a pretext for the residents to intensify their protests.

On that same day, the president of Fiocruz was in Manguinhos and talked to Captain Toledo, then in charge of the UPP, in the presence of members of the Human Rights Committee of the State Assembly of Rio de Janeiro, family members, and other Fiocruz employees. His speech emphasized the concern that the residents did not suffer any kind of reprisal, and that their "right to come and go [was] guaranteed." Those present at this meeting also accused the police of swearing at female residents, calling them 'whores,' and that one officer had placed his rifle nozzle on the chest of one of Paulo Roberto's sisters.

The family decided to hold his wake at the headquarters of the residents' association at the João Goulart Park, located in front of the square where the flag symbolizing the 'reoccupation' of the territory of Manguinhos by 'pacification' had been hoisted. During the wake, Fátima Pinho Menezes, mother of the murdered young man, said that her son's death was the result of police persecution - a persecution that she attributed to the fact that her son had been sentenced to social and educational rehabilitation measures. In addition, during her speech she exposed the procedures adopted by the State organs that had issued the official version of her son's death, and, again, the central role of the Emergency Care Unit in substantiating the version presented by the police:

18 In a statement, the UPP press office declared that "Police officers from the Pacifying Police Unit (UPP) of Manguinhos did a routine search on Wednesday Moring (03/20) on a 16-year-old minor in Vila Turismo community. During the search, nothing was found on him, and he was subsequently released. According to witness information, the young man was under the influence of drugs and passed out minutes later. He was then sent to the Manguinhos UPA [Emergency Care Unit], where he died. The information regarding police violence through the use of Taser shock equipment is unfounded, since the Unit does not yet have this type of non-lethal equipment. According to the doctors from the Emergency Care Unit, the young man's body did not show any sign of violence as a consequence of the use of such equipment." (http://extra.globo.com/casos-de-policia/moradores-de-manguinhos-acusam-policial-de-uppde-ter-matado-jovem-com-choque-pm-nega-7894149.html\#ixzz4WndohiSm). 
They [the police] took my son together with three or four other boys. They left just my son in the alley to kill my son. Why my son? It was persecution! My son could not walk through Coréia, or a guy they call Martelo [Hammer] would start threatening my son, you know? Then, he [the policeman quoted] would move from one to another, threatening all the kids in the community who he called rebellious. He pointed to them one by one, saying that each of them was going to die at dawn. Unfortunately they managed to get my son and kill him down the alley. Now my son is seen as a drug dealer, a drug user. Whether or not he had been sentenced to social and educational rehabilitation, there was no justification for what they did to my son. Whether he was using drugs or not, it did not justify the police taking my son into the alley and killing him. The police had to arrest him, take him into custody in the police station, if he really was using drugs. Now, they cannot just say that he had a bottle of loló [a blend of chloroform and ether used as a narcotic], because when I arrived there by my son's body, my son breathed in twice and died in my lap, and he was not carrying anything, he had nothing! They said that they had called an ambulance, they did not call for it! [...]. They did not help my son, they left my son to die there in the alley, another one thrown to the ground, because I went there and found my son, thrown on the ground like an animal, all wet with blood in his mouth. [...] He had already killed my son, suffocated him there [yet they] said that my son arrived alive at the UPA. My son did not arrive alive, my son arrived dead. And the UPA was negligent with my son, do you know why? They said that they had been trying to resuscitate him for an hour. And I wanted to go in with my daughter-in-law to see my son, [but] they would not let us in, [the person] who was going in was the guy from the UPP. All the time a cop would go in, another cop would come out, one communicated with another, another cop would go in, to see the shit that they had done there, because when they saw what they had done to my son in the corner, [the police officers] said to each other, "we fucked up," because they had already killed my son in the alley. It won't remain like this. Whatever I can do for my son, I'm now going to do. ${ }^{19}$

Paulo Roberto's death brings to the fore another way in which the state relates to populations and territories considered to be marginal: while in Mateus's case it proved impossible to confirm that the firing of the Taser weapon had hit his body, since no injury was found, in the case of Paulo Roberto's murder, the proximity of law enforcement agents to the body of the victim is evident. Nothing was fired - neither a firearm nor an electroshock weapon - but the physical contact between local UPP officers and the young resident clearly resulted in his death.

In order to continue this analysis, it is important to engage with another type of official statement concerning the murder in question. In Mateus's case, the UPP commander's explanation during the community meeting was used as data to be analyzed. In the case of Paulo Roberto, we look at the official statement that the Military Police released on that same day:

According to the commander of the Manguinhos Pacifying Police Unit (UPP), Captain Gabriel Toledo, around 3:15am this Thursday (17/10), police officers on routine patrol, in the locality known as Barrinho, spotted four young men acting suspiciously, and as they approached the group, one of the young men fled towards an alley. Visibly disturbed, he collapsed even before being captured by the police. The agents placed the unconscious young man inside the police car and took him to the Manguinhos UPA. According to the doctor who assisted the young man, he already arrived dead at the medical unit. The causes of the young person's death will only be known after an autopsy is performed by the Medical-Legal Institute. The young man was identified as Paulo Roberto Pinho de Menezes, 18 years old. According to police officers' statements, the young people who were with Paulo Roberto stated that he had inhaled loló minutes before the incident. The incident was registered at the $21^{\text {st }}$ Police Department (Bonsucesso). ${ }^{20}$

19 Fátima Pinho de Menezes, during the funeral and demonstration in protest over her son's death, held on October 18, 2013.

20 Note published in the Jornal do Brasil newspaper report “Moradores protestam contra morte de jovem na Favela de Manguinhos" - 17/10/2013. Source: http://www.jb.com.br/rio/noticias/2013/10/17/moradores-protestam-contra-morte-de-jovem-na-favela-de-manguinhos/. 
Police patrolling continues to be routine - after all, this is just another practice carried out by UPP officers, a project that, inspired by models of 'proximity policing,' has been renewing and developing different forms of approximation, among which we highlight this way of approximating vigilance and control of the residents of favelas and peripheries where UPPs are installed. To consider the behavior of young people - the majority, black favela residents - as suspicious is one of the common practices of these police officers, state employees who work for the Secretary of State for Public Security (SESEG), an indispensable section of the government when it comes to ensuring the operation of a public administration traversed by what Foucault (2005) called the "mute mechanism of a state racism."

The large number of people who witnessed the police approach the young man, as well as statements from the mother and other family members about the procedures adopted by the emergency care unit (UPA) employees, are exploited as elements to form a version of the facts that contributes to depicting Paulo Roberto's killing as the death of someone marked by 'prior criminalization' (Leite 2008:118), and to reinforcing stigmas that make it more difficult for family members to gain access to justice. It is possible, therefore, to point to a similarity between the State agents' statements concerning the deaths of Mateus and Paulo Roberto, since both trigger elements that stigmatize the victim as a drug user, or set out by assuming their "dubious morality" (ibid:119) as person involved in drug trafficking.

According to the government version of events, Paulo Roberto also suffered a fall just like Mateus. This could be another form of approximation in which the kind of proximity policing being developed by UPPs continues to specialize: bringing bodies closer to the ground - a practice already praised by another SESEG division, the Special Police Operations Battalion (BOPE), who, during their military training, sing "men in black, what is your mission? Enter the favela and leave bodies on the ground." Such an overlapping of body/territory (or lifeless body/ground) can be read as the production of another margin, closer to the kind defined by Das and Poole (2004:9) as "places where rights can be violated through different dynamics of interaction between people using the documents, practices and words of the State," as we cited in the introduction. Following Barros's line of thought, by updating certain public policies in peripheral regions of the city through simultaneous interventions in territories and bodies, "the state produces the margins it needs for its own practices" (Barros 2016:288).

Two months after Paulo Roberto's death, a complementary report from the Medical-Legal Institute confirmed that the young man had died from mechanical asphyxia, which contradicted the first statement of the UPP commander. Five police officers were detained for 30 days, and the pacifying police command launched an inquiry, independent of the investigation already taking place at the $21^{\text {st }}$ Police Station. ${ }^{21}$ This development, which afforded legitimacy to the statements of the relatives and the mother, was considered a great victory, especially for having yielded results in a very short time when compared to most homicide cases linked to police intervention in favelas.

Investigations were ongoing and the inquiry was only completed a year and a half after the young man's death. In May 2015, the five police officers were indicted for bodily injury followed by death, and the toxicology report belied the previous examination, which alleged that the young man had died from a set of circumstances, including use of the drug known as 'cheirinho de loló.' ${ }^{22}$

\footnotetext{
21 “Cinco policiais são indiciados por homicídio de jovem," source: <http://brasil.estadao.com.br/noticias/geral,cinco-policiais-de-upp-sao-indiciados-porhomicidio-dejovem,1103237>. Consulted: 02/03/2016.

22 It is worth mentioning that the indictment for "bodily injury followed by death" mitigates the circumstances of Paulo Roberto's death, removing the possibility of indicting the police for homicide.
} 


\section{May $14^{\text {th }}$ 2014: the case of Johnatha de Oliveira}

On May $14^{\text {th }}$ 2014, Johnatha de Oliveira was murdered, shot in the back near the house of Fatima Pinho, whose son had also been murdered seven months earlier in the same region, as we discussed above. Johnatha had gone to his grandmother's house to bring her a cake made by his mother. He then went to take his girlfriend home and, on returning to his own home, was hit by the bullet. It was late afternoon, precisely when children are leaving school to go home, and yet local UPP officers fired gunshots toward residents in a region where many children were outside playing. As with several other homicide cases, the mainstream media reported Johnatha's death as the outcome of a shootout between the police and drug dealers, and the young man was himself treated as a trafficker. ${ }^{23}$

Because Johnatha was killed by a gunshot, the cause of his death allowed no room for different discursive constructions, as happened in the cases of Mateus and Paulo Roberto. But while the cause of death is undisputed, government agents make use of its rationalized discursive strategies concerning the circumstances and other factors related to the homicide in question, mobilizing the parts necessary to the functioning of its "mechanisms of management of deaths of favela residents" (Farias 2014:18) that operate during militarized actions/occupations.

An engagement with another sequence of official narratives helps strengthen this argument. In this case, we decided to bring to the analysis excerpts from documents that the state produces to construct its narrative. We begin this part of the discussion with the 'external inspection' section of the autopsy report, in which the injuries caused by the weapon used by local UPP agents are described in detail:

...presence of an oval wound, with a more pronounced margin of excoriation in the lower right quadrant of the lesion, with inverted edges and infiltrated by blood, with characteristics of those produced by firearm projectile entry, located in the sacrococcygeal region. ${ }^{24}$

The 'internal inspection' section of the same document complements this description:

...there is an injury to the left iliac artery and vein; in the musculature of the anterior abdominal wall, in the topography of the left iliac fossa, we find a firearm projectile coated with yellow metal; [...] an identified and sealed envelope containing the firearm projectile removed from this corpse was given to the official responsible for the Forensic Data Sector according to Order of Service number 012/2010, ${ }^{25}$

The conclusion presented in Johnatha's autopsy report leaves no doubt about the cause of death:

...the victim was struck by a single shot of a firearm projectile that penetrated the abdomen after traversing the sacral bone, with an ascending oblique path, from right to left and from the back to the front; from examination of the garments there is no evidence of shooting at close range; the projectile is not of high kinetic energy. ${ }^{26}$

As we stated earlier, however, accurately determining the cause of death does not mean invoking a single version of the facts. Analyzing the "answers to the questions" of the Autopsy Report on Johnatha's body, it is possible to note that the answers to questions 1, 2 and 3 may contribute to a particular version of the facts:

23 "Base de UPP em Manguinhos é atacada durante manifestação." Source: http://oglobo.globo.com/rio/base-deupp-em-manguinhos-atacada-durantemanifestacao-12489691\#ixzz47K3lfxYg. Consulted: 02/03/2016.

24 Autopsy Report - IML-RJ-SNCo23878/2014.

25 Autopsy Report - IML-RJ-SNCo23878/2014

26 Autopsy Report - IML-RJ-SNCo23878/2014. 
1) Was there death?

YES.

2) What was the cause of death?

A PENETRATING INJURY TO THE ABDOMEN, WITH VASCULAR AND INTESTINAL INJURY, WHICH DETERMINED SUBSEQUENT INTERNAL HEMORRHAGE.

3) What was the instrument or medium that caused the death?

\section{FIREARM PROJECTILE. ${ }^{27}$}

Nonetheless, it is important to look at the manner in which the fourth question is answered: "(4) Was it caused by poison, fire, explosive, suffocation or torture, or by insidious or cruel means (specified response)? NO ELEMENTS TO ANSWER THIS QUESTION DUE TO A LACK OF KNOWLEDGE REGARDING THE DYNAMICS OF THE EVENT." ${ }^{28}$ This answer reflects a pattern concerning homicides that result from police intervention, since it removes the impact that the autopsy report could have on the investigation and, later, on the judicial process. Had the marks produced by the State on the victim's body also been imprinted on the surface of the paper, this would have revealed that the homicide in question was indeed a case of summary execution. Such a way of answering without informing, without saying anything, is one of the techniques used in the bureaucratic administration of the deaths of favela residents: it is a procedure that, instead of hiding information, reveals the power of a "bureaucratic unspoken, because it reveals the intimacy of the specialist with an economy of words in a document that is crucial to the judicial/legal treatment of state crimes and violations" (Farias 2014: 172).

The practice of standardizing answers in the report continues in the fifth question by pointing the reader to another section of the same document: " 5 ) other objective considerations related to the traces produced by the death, at the discretion of the Forensic Expert. SEE CONCLUSION." ${ }^{29}$ In order to interpret regular procedures like this one - which, it is worth remembering, occur within a public office of the State Secretariat of Public Security of Rio de Janeiro ${ }^{30}$ (SESEG) - we can connect the ways in which the Autopsy Report's answers are written to the problem of the illegibility of State documentation, which, seen through the analytical tools proposed by Das and Poole (2004), shows this connection to be one of the bases for consolidating state control over populations, territories and lives.

We are again faced with the operation of a new "discursive orthopedics" (Foucault 1988) within the very mechanisms of government management of these deaths. This kind of orthopedics is also performed in the production of information to be publicized through the treatment of these deaths as state statistics. Even though such data is predominantly presented as unquestionable, formulated as in the exact sciences, statistics on deaths may also be permeated with obscurity. Not because statistics were poorly calculated, but because such a calculation is already produced in order to emphasize certain numbers over others, to value quantitative arrangements that allocate within the same set information that should appear separately.

\footnotetext{
27 Autopsy Report - IML-RJ-SNC023878/2014.

28 Autopsy Report - IML-RJ-SNC023878/2014.

29 Autopsy Report - IML-RJ-SNC023878/2014

30 We emphasize that the Afrânio Peixoto Medical-Legal Institute is part of the structure of the Civil Police of the State of Rio de Janeiro (PCERJ), specifically the institution's Technical-Scientific Police Department. The PCERJ is part of the executive branch of the State of Rio de Janeiro, which is itself part of the Secretariat of State for Public Security (SESEG).
} 
This is the case, for example, of homicides that are recorded as "violent deaths of undetermined cause" by different federal states: according to recent IPEA ${ }^{31}$ research, using data from the Mortality Information System (SIM), the homicide rate in Brazil is 18.3\% higher than the figures in the official records - a percentage which indicates that eight thousand and six hundred homicides per year in Brazil are wrongly classified as "violent deaths of undetermined cause" (Cerqueira 2013).32

Presented as a "Map of Hidden Homicides," the very title of the IPEA research contains the notion of information that is not made available, erased from official records. In previous research conducted specifically with homicide data from the city of Rio de Janeiro, IPEA had reported that the neighborhoods where most of these crimes occur correspond to the regions where approximately $60 \%$ of the city's favelas are located (Rivero \& Imanishi 2009). The same research revealed that lethal police work is concentrated in the same areas: in favelas or adjacent areas.

Although the cause of death is undeniable in the case of Johnatha's execution, the narratives of the police officers involved in the crime point to the recurrent version of shootout confrontations also found in other documents from the police inquiry into the case, as well as adding the information that a bag with a certain amount of narcotic substances had been seized, as registered in the "Results of Police Proceedings" attached to the investigation. ${ }^{33}$ Despite the strategies used to deny that shots were deliberately fired and to conceal the information relating to authorship of the crime, in the second hearing conducted by the special operations police station, one of the agents admitted to having fired shots on the occasion, claiming that "this was done because he sought to hit armed individuals who were hiding behind residents." ${ }^{34}$

It is unnecessary to be an expert mathematician to undertake some basic calculations. Similarly, one does not need to understand "something of shooting, of weaponry" (as Captain Martins demanded in the community meeting mentioned in the first section of this article) to know that if one aims to shoot people who are standing behind others, the chances of hitting those in front are greater. This police practice can be seen when police officers from UPP Manguinhos fired shots in the direction of residents during the protests over Mateus's death on May 14, 2014, and in the same way when another agent fired the bullet that struck Johnatha's body from behind.

There are no records in the report to indicate that the firing was carried out at close range - which allows us to imagine that this time the police were not close to the victim at the moment he was hit, as occurred in the other two cases discussed. Nevertheless, we consider it pertinent to draw attention to the fact that it is not necessary for the agent to move closer in order for the state to ensure control over residents' bodies, since, like Mateus and Paulo Roberto, Johnatha also had his body 'grounded' due to a police officer's action while on duty.

\section{Electric shocks, beatings and firearm shooting}

What is the notion of proximity that guides the three episodes of violence discussed in this article? From what distances - political, geographical, moral - is this marketed notion of proximity developed by the State Government?

\footnotetext{
31 IPEA - Institute of Applied Economic Research

32 Similar movement can be observed in relation to the treatment of data on forced disappearances. According to Araujo (2012), between 1991 and May 2014, the State of Rio recorded 92,000 cases. However, many cases that are reported as disappearances correspond in fact to murders committed by state agents, especially agents who belong to militia groups, but also murders practiced by drug traffickers.

33 Police Inquiry number 901-00563/2014. Homicide Division / General Department of Specialized Police / Civil Police Chief / State Secretariat of Security - SESEG / Rio de Janeiro State Government.

34 Police Inquiry number 901-00563/2014. Homicide Division / General Department of Specialized Police / Civil Police Chief / State Secretariat of Security - SESEG / Rio de Janeiro State Government.
} 
The Pacifying Police Unit (UPP) has been one of the most important public security programs in Brazil in recent decades. Implemented by the SESEG, at the end of 2008, the UPPs Program - planned and coordinated by the Sub-Secretariat for Planning and Operational Integration - was elaborated according to the principles of Proximity Policing, a concept that goes beyond community policing and whose strategy is based on the partnership between the population and the institutions of Public Security. ${ }^{35}$

Among the governance technologies of territories and bodies discussed here, it was possible to explore a number of distinct approaches in terms of proximity. "Small distance; small time interval; imminence" appear in the dictionary as one of the meanings for the word 'proximity,' along with "condition of what is or is close to (something); neighborhood, contiguity.” Both meanings of the term challenge us to establish connections with the idea of a "partnership between the population and public security institutions" as presented on the government's website.

Returning to the case of Mateus Casé's death, the community meeting could be read as a moment of approach by the local UPP command to the residents of Manguinhos. However, we draw attention to the excerpt from the captain's narrative regarding the Taser dart shot. The description of the possibility of perforation, the information that the dart imprints on the skin, can be read in two ways: on one hand, for the most obvious reason, it is articulated with the denial of the version of events that accuses the police of Mateus's death (after all, his body did not present lesions), and, on the other, it is a situation in which the power asymmetry between the UPP captain and residents can also be actualized through the announcement of the exemplary punishment - the body of Mateus did not bear marks, but the bodies of other residents can be marked: after all, the dart "pierces the skin" so that only a medical team can remove the object.

In a "short period of time," the long-distance shot fired by the Manguinhos UPP officer resulted in the perforation of Johnatha Oliveira's body. During an interval of time that remains unknown to us, the repetitive connecting of arms and legs - via punches and kicks - with the body of Paulo Roberto Menezes resulted in the mechanical asphyxia of the second fatal victim after the UPP's installation in the territory in question. Seconds after the electric shock fired by the Taser weapon, which is not part of the list of equipment available to the agents of the same UPP, Mateus Casé's body fell to the ground, never to stand up again.

In all three situations, the proximity to the UPA (emergency care unit) was also a factor, so that Mateus, Paulo Roberto and Johnatha were taken there by other residents, but all three were already dead on arrival..$^{36}$ The proximity of the different armaments (even considering the uniform of the agents) also impacts on the present reflection: the circumstances of Mateus's death produced a body "without lesions," while the injuries to the bodies of Paulo Roberto and Johnatha led the investigations. The political proximity of the three bodies is also what brought them closer to the ground in the three cases analyzed here, and in many other cases of homicide resulting from police intervention, as ratified by the speech of Ana Paula, mother of Johnatha:

My son was murdered at the age of 19 years with a shot in the back, totally defenseless. My son reached the Manguinhos UPA lifeless, he had internal hemorrhaging and was rescued by residents. And unfortunately he was not the only victim of the UPP Manguinhos. Five young people have already been killed in Manguinhos.

35 Unidade de Polícia Pacificadora. O que é? Source: http://www.upprj.com/index.php/o_que_e_upp. Consulted: 10/12/2016.

36 Although we cannot explore the topic in this article, we highlight the relevance of a reflection on how the routine practices surrounding the arrival of corpses at emergency care units feed this mechanism of bureaucratic management of the deaths of residents of favelas and urban peripheries. Barros (2016) opens some new avenues for this debate, informing us that during a meeting held the day after the burial of Paulo Roberto, a meeting was held on violence in Manguinhos where several Fiocruz workers contributed to the problematization of the performance of health professionals in the episode of his death as a case to be dealt with by the institution. Those present said that the UPA's negligence in assuming that the young man was dead, providing the asphyxia death report without mentioning the visible injuries on the young man's body, and only allowing police officers to enter the medical unit, should be taken as a problem to be faced by FIOCRUZ. 
[...] Today my life is [devoted] to joining other mothers, being in the struggle bearing my son's name, taking my pain, bringing my cry of love for my son, seeking justice, a justice that for those of us who are poor, favela residents... we only know such justice when it comes to arrest us, when it comes to punish us. ${ }^{37}$

As a counterpoint to governmental proximity, other political and analytical paths may open up through the movements of mothers and relatives of the victims of state violence. According to Barros's analysis (2016), the presence of Fátima Pinho and Ana Paula Oliveira in the Manguinhos Social Forum contributes to the production of another atmosphere for the debate on urban violence that radiates into the favelas of Manguinhos..$^{38}$ The expertise acquired by these women to master the reading of reports, to follow up procedures, to know the positions of the judges, to know which organizations to reach out to in different situations, forcing them to do their work, and so on, builds a repertoire of skills on how to act within the state bureaucracy. Shared with other mothers and relatives, these relocate the residents of favelas and urban peripheries in the asymmetric mosaic of power distribution in militarized contexts. ${ }^{39}$

We close this discussion, therefore, by referring to the motivation expressed in the title of this article: the notions of center and periphery were explored through an engagement with the bodies of the victims, the types of speeches, armaments and forms of state action employed in favela territories. The idea of proximity policing itself allows for new reflections on these geographical and political demarcations.

We consider the bodies of the three victims as the center toward which the violent actions of State agents are directed. The contact with these bodies does not occur in the same way since, as we have seen, the first two deaths occurred through actions considered "less lethal," which can be refuted with greater ease, and which for these reasons we here call peripheral.

In the first case with which we engaged, the death of Mateus Casé happens from the periphery to the center. His body is touched by an armament defined as non-lethal and that in theory would not pose the risk of death. This homicide was exemplary, however, in terms of showing that the practices and discursiveness associated with the allegedly humanized procedure adopted by the UPP do not rule out the possibility of violent action. On the contrary, such discourses and practices that make use of technical arguments may serve to delegitimize the versions of residents and activists concerning these crimes.

In the case of the death of Paulo Roberto, the contact with the body is also peripheral because it once again involved procedures that in theory would not be associated with lethality. Unlike the first case, though, the proximity with the agent of the state increases, since here the crime is directly associated with the use of physical force by the policeman. Even though in this case there was also room for a discourse that minimized police lethality and blamed the victim - the arguments about his use of narcotics, the cause of death by falling, not suffocation - his body bore the marks of police violence, identified in the postmortem report as "mechanical asphyxia," which made it possible to challenge the 'official' version of the event more decisively.

37 Testimony of Ana Paula Oliveira during the demonstration "The multiple violences, racism and sexism kill favela women every day," held on December $9^{\text {th }} 2015$ in Largo da Carioca, as the final activity of the work developed by the non-governmental organization FASE.

38 Nine months after Johnatha's murder, on February $9^{\text {th }}$ 2015, the first hearing of his case took place. In September of the same year, the first hearing of the case of Paulo Roberto occurred. In both cases, the same pattern of mobilization of activists via social networks was seen in order to organize demonstrations in front of the Court of Justice of Rio de Janeiro before the beginning of each hearing. Both cases are still ongoing - the case of Jonhatha Oliveira is being judged in the Jury Court, while the case of Paulo Roberto Menezes is being assessed by the Military Court.

39 The paths taken by these family members require a certain acceleration in the development of specific competences, both for updating the repertoires for mobilizing people and action - corresponding to what Boltanski (2000) calls the "making of the political" - and for various types of public intervention. The engagement of Fátima Pinho and Ana Paula Oliveira in the Manguinhos Social Forum is situated in a context of the consolidation of sequential and comprehensive political movements that directly interfere in the "elaboration of public problems" in the terms proposed by Freire (2005, 2007, 2008, 2010). Regarding the protagonism of mothers and family members of the victims of state violence in their fight for justice, we highlight the work of Leite (2004), Vianna (2014) and Vianna and Farias (2011), as well as the work of Moura (2007), Soares, Moura \& Afonso (2009), Araujo (2007, 2008 and 2012) and Freire (2010). For an analysis of the political collectives organized by relatives against other instances of violence in Brazil, see Ferreira (2011) and Lacerda (2012). For analyses produced on the Argentine context, besides Catela (2001), see Bermúdez (2010). 
With Johnatha's death, despite his body being the furthest away from a police officer, the fact that he was struck by a projectile overcomes the gradual barriers of violent contact. In this case, the way in which the body was struck throws into question the police action, because while in the previous deaths there was a dispute between defense and critique of the proximity practices adopted by the police, here we have the repetition of the logic of coercive control with the use of lethal ammunition that pierces the body, nullifying the idea of any positive interaction between police and population.

According to Talal Asad (2004), when the relationship between the state and the governed population is understood as a way through which the state embodies sovereignty regardless of its population, it becomes authorized to maintain certain spaces and populations as marginal through administrative practices. In accord with this statement, we have seen that in these three cases, practices carried out under the label of 'proximity' enable us to understand how the population residing in favela spaces, and more specifically their bodies, are traversed by technologies of control that rely on discursive practices to make invisible or recreate the boundaries between the lethal and non-lethal.

In this sense, the displacements between center and periphery pass through the frayed borders between bodies and territories: the complexity of the techniques of governmental control shift from discourses to practices, they move from territories to bodies, imposing their refinement on these populations. This is why we believe in the centrality of the idea of margins as a possibility for deepening the reflections on state action. We strongly hope to have contributed to this discussion with this article.

Translated by Ana Luiza Lopes and Rodrigo Calvet

Received: January 26, 2017; Approved: May 26, 2017 


\section{References}

ARAÚJO, Fábio A. 2007. Do luto à luta: a experiência das Mães de Acari. Dissertação de Mestrado. Programa de Pós-Graduação em Antropologia e Sociologia (PPGAS). UFRJ, Rio de Janeiro.

. 2008. "Falta alguém na minha casa: desaparecimento, luto, maternidade e política". In: Roberto Kant de Lima (ed.), Antropologia e direitos humanos V. Brasília: Booklink. pp. 166-225.

. 2012. Das consequências da 'arte' macabra de fazer desaparecer corpos: violência, sofrimento e política entre familiares de vítima de desaparecimento forçado. Tese de doutorado. Programa de Pós-Graduação em Antropologia e Sociologia (PGSA). UFRJ, Rio de Janeiro.

ASAD, Talal. 2004. "Where are the margins of the State?" In: Veena Das andDeborah Poole (eds.), Anthropology in the margins of the State. New Mexico: School of American Research Press. pp.279-288.

BARROS, Rachel. 2016. Urbanização e "pacificação" em Manguinhos: Um olhar etnográfico sobre sociabilidade e ações de governo. Tese de Doutorado - Universidade do Estado do Rio de Janeiro, Instituto de Estudos Sociais e Políticos.

BERMÚDEZ, Natalia. 2010. Y los muertos no mueren: uma etnografía sobre clasificaciones, valores morales e prácticas em torno a muertes violentas. (Córdoba - Argentina). Buenos Aires: Editorial Académica Española.

BIRMAN, Patricia. 2008. “Favela é comunidade?” L.A. Machado da Silva (ed.), Vida sob cerco: violência e rotina nas favelas do Rio de Janeiro. Rio de Janeiro: FAPERJ/Nova Fronteira. pp. 99-114.

BIRMAN, P.; LEITE, M.; MACHADO. C; CARNEIRO, S. (eds.) 2015. Dispositivos urbanos e trama dos viventes: ordens e resistências. Rio de Janeiro: Editora FGV.

BOLTANSKI, Luc. 2000 [1990]. El amor y la justicia como competencias: tres ensayos de sociología de la acción. Buenos Aires: Amorrortu Editores.

CATELA, Ludmila. 2001. Situação-limite e memória: a reconstrução do mundo dos familiares de desaparecidos da Argentina. São Paulo: Hucitec/ Anpocs.

CERQUEIRA, Daniel. 2013. Mapa dos homicídios ocultos. Texto para Discussão no 1848 . Instituto de Pesquisa Econômica Aplicada. Brasília/ Rio de Janeiro : Ipea.

CLAVERIE, E. 1998. "La naissance d'une forme politique: l'affaire du Chevalier de La Barre”. In: P. Roussin (ed.), Critique et affaires de blasphème à l'Epoque des Lumières. Paris: Honoré Champion. Pp 185-26o.

CUNHA, Neiva Vieira da Cunha; FELTRAN, Gabriel (eds.). 2013. Sobre periferias: novos conflitos no Brasil contemporâneo. Rio de Janeiro: Lamparina / FAPERJ.

DAS, Veena; POOLE, Deborah. 2004. State and its margins: comparative ethnographies. In: Anthropology in the margins of the State. New Mexico: School of American Research Press.pp3-33.

FARIAS, Juliana. 2015. "Da capa de revista ao laudo cadavérico: pesquisando casos de violência institucional em favelas cariocas". In: P. Birman et al. (eds.), Dispositivos urbanos e trama dos viventes: ordens e resistências. Rio de Janeiro: Editora FGV. Pp419-449.

. 2014. Governo de mortes: uma etnografia da gestão de populações de favelas no Rio de Janeiro. Tese de Doutorado. Programa de Pós-Graduação em Sociologia e Antropologia - PPGSA/UFRJ.

FELTRAN, Gabriel. 2011. Fronteiras de tensão: política e violência nas periferias de São Paulo. Editora UNESP

FERNANDES, Adriana. 2013. Escuta ocupação - arte do contornamento, viração e precariedade no Rio de Janeiro.

Tese de doutorado. Programa de Pós-Graduação em Ciências Sociais, Universidade do Estado do Rio de Janeiro.

FERREIRA, Letícia. 2011. Uma etnografia para muitas ausências: o desaparecimento de pessoas como ocorrência policial e problema social. Tese de Doutorado. UFRJ/ Museu Nacional/ Programa de Pós-Graduação em Antropologia Social .

FOUCAULT, Michel. 1988. História da sexualidade I: a vontade de saber. Rio de Janeiro: Edições Graal. 
2005. Em defesa da sociedade: curso no Collège de France (1975-1976). São Paulo: Martins Fontes.

FREIRE, Jussara. 2005. Sensos do justo e problemas públicos em Nova Iguaçu. Tese de Doutorado, IUPERJ. . 2007. "Percepções de justiça e competências políticas em Nova Iguaçu (RJ)". Ciências Sociais

Unisinos, 43: 157-161. . 2008. "Elevar a voz em uma ordem violenta: a indignação colocada à prova pelo silêncio". In: L.A. Machado da Silva (ed.), Vida sob cerco: violência e rotina nas favelas do Rio de Janeiro. Rio de Janeiro: FAPERJ/ Nova Fronteira. Pp143-172.

2010. "Quando as emoções dão formas às reivindicações". In:Maria Claudia Coelho and Claudia Barcellos Rezende (eds.), Cultura e sentimentos - ensaios em antropologia das emoções. Rio de Janeiro: FAPERJ. pp.168-196.

GUARIENTO, Suellen. 2009. Mobilizações sociais e violência: diferentes discursos e a trajetória de um movimento social. Monografia de conclusão de Graduação em Serviço Social. Universidade Federal do Rio de Janeiro, UFRJ, Brasil.

GUTERRES, Anelise. 2016. “O rumor e o terror na construção de territórios de vulnerabilidade na zona portuária do Rio de Janeiro". Mana. Estudos de Antropologia Social, 22(1): 179-209.

LACERDA, Paula. 2012. O "caso dos meninos emasculados de Altamira": polícia, justiça e movimento social. Tese de Doutorado. UFRJ/ Museu Nacional/ Programa de PósGraduação em Antropologia Social.

LANDIM, Leilah. 2013. "Violência e organizações civis na periferia do Rio de Janeiro: novas cartografias?" In: Neiva Vieira da Cunha; Gabriel Feltran (eds.), Sobre periferias: novos conflitos no Brasil contemporâneo. Rio de Janeiro: Lamparina / FAPERJ.

; GUARIENTO, Suellen. 2010. "Violência e ação coletiva na Baixada Fluminense. Paper apresentado no 34을 Encontro Anual da ANPOCS. ST31S1; Mimeo.

; SIQUEIRA, Raíza. 2013. Trajetos da violência, da segurança pública e da sociedade civil na cidade do Rio de Janeiro. Textos para discussão. 1821. Brasilia-Rio de Janeiro: IPEA.

LEITE, Márcia. 200o. "Entre o individualismo e a solidariedade: dilemas da política e da cidadania no Rio de Janeiro". Revista Brasileira de Ciências Sociais, 15(44): 73-90.

. 2004. "As mães em movimento". In: Patrícia Birman et al. (eds), Um mural para a dor: movimentos cívico religiosos por justiça e paz. Porto Alegre: Editora da UFRGS. Pp141-19o.

. 2008. "Violência, risco e sociabilidade nas margens da cidade: percepções e formas de ação de moradores de favelas cariocas". In: Luiz Antônio Machado da Silva (ed.), Vida sob o cerco: violência e rotina nas favelas do Rio de Janeiro. Rio de Janeiro: Nova Fronteira. Pp115-141.

2012. 'Da 'metáfora da guerra' ao projeto de 'pacificação': favelas e políticas de segurança pública no Rio de Janeiro". Revista Brasileira de Segurança Pública, 6(2):374-389.

MACHADO DA SILVA, L. A. 2016. Fazendo a cidade: trabalho, moradia e vida local entre as camadas populares urbanas. Rio de Janeiro: Mórula.

. 2008 (ed.). Vida sob cerco: violência e rotina nas favelas do Rio de Janeiro. Rio de Janeiro: FAPERJ/Nova Fronteira.

MAGALHÃES, Alexandre2013. Transformações no "problema favela" e a reatualização da "remoção" no Rio de Janeiro. Tese de Doutorado, Instituto de Estudos Sociais e Políticos, Universidade do Estado do Rio de Janeiro.

. 2008. Entre a vida e a morte: a luta! A construção da ação coletiva por moradores de favelas no Rio de Janeiro. Instituto Universitário de Pesquisas do Rio de Janeiro. Programa de Pós-Graduação em Sociologia. Dissertação de Mestrado.

MATTOS, Carla. 2013. Viver nas margens: gênero, crime e regulação popular de conflitos. Tese de doutorado. Programa de Pós-graduação em Ciências Sociais da Universidade do Estado do Rio de Janeiro - PPCIS. 
MENEZES, Palloma. 2015. Entre o "fogo cruzado" e o "campo minado": uma etnografia do processo de "pacificação" de favelas cariocas. Tese de Doutorado em Sociologia - Instituto de Estudos Sociais e Políticos, Universidade do Estado do Rio de Janeiro.

MOMBAÇA, Jota. 2016. "Rumo a uma distribuição desobediente de gênero e anticolonial da violência!" Cadernos de Imaginação Política. Source: https:/|issuu.com/amilcarpacker/docs/rumo_a_uma_ redistribuic__a__o_da_vi Consulted: 20/12/2016.

MOURA, Tatiana. 2007. Rostos invisiveis da violência armada: um estudo de caso sobre o Rio de Janeiro. Rio de Janeiro: 7 Letras.

RIVERO, Patrícia and IMANISHI, Rute. 2009. Indicadores socioeconômicos de proteção e risco para a instrumentação de políticas públicas em favelas. Instituto de Pesquisa Econômica Aplicada. Brasília/ Rio de Janeiro: Ipea.

ROCHA, Lia. 2013. Uma favela 'diferente das outras'? Rotina, silenciamento e ação coletiva na favela do Pereirão no Rio de Janeiro. Rio de Janeiro: Quartet.

RODRIGUES, A.; CASANOVA, C.; SIQUEIRA, R.; MENDONÇA, T.; GUARIENTO, S. 2012. "Pensando as associações de moradores no contexto das UPPs". In: A. Rodrigues et al. (ed.), Unidades de Polícia Pacificadora: debates e reflexões. Comunicações do Iser, 67(31): 53-79.

SOARES, Barbara Musumeci; MOURA, Tatiana; AFONSO, Carla (eds.). 2009. Auto de resistência: relatos de familiares de vítimas da violência armada. Rio de Janeiro: 7 Letras.

TELLES, Vera. 2010. As cidades nas fronteiras do legal e do ilegal. Belo Horizonte: Argumentum.

TRINDADE, Claudia. 2012. "Não se faz omelete sem quebrar os ovos". Política Pública e participação social no PAC

Manguinhos - Rio de Janeiro. Tese de Doutorado. Universidade Federal Fluminense, Instituto de Ciências Humanas e Filosofia, Departamento de História.

VALLADARES, Lícia. 2000. "A gênese da favela carioca: a produção anterior às ciências sociais". Revista Brasileira de Ciências Sociais, 15(44): 5-34. . 2005. A invenção da favela: do mito de origem a favela.com. Rio de Janeiro: FGV Editora.

VIANNA, Adriana. 2014. "Violência, Estado e gênero: entre corpos e corpus entrecruzados". In: Antônio Carlos de Souza Lima; Virginia Garcia-Acosta (org.), Margens da violência: subsídios ao estudo do problema da violência nos contextos mexicano e brasileiro. 1ed. Brasília: ABA. v. 1, pp. 209-237.

VIANNA, Adriana; FARIAS, Juliana. 2011. "A guerra das mães: dor e política em situações de violência institucional”. Cadernos Pagu, 37: 79-116.

\section{Rachel Barros}

CIDADES - Urban Research Nucleus, Graduate Program in Social Sciences - PPCIS, Rio de Janeiro State University - UERJ, Rio de Janeiro/RJ, Brazil.

E-mail: r.barrosdeoliveira@gmail.com

\section{Juliana Farias}

CIDADES - Urban Research Nucleus, Graduate Program in Social Sciences - PPCIS, Rio de Janeiro State University - UERJ, Rio de Janeiro/RJ, Brazil.

E-mail: farias.ju@gmail.com 